\title{
Assessment of individuals with aphasia: an integrative literature review
}

\author{
Emilyn Borba da Silva ${ }^{1}$ \\ https://orcid.org/0000-0002-5861-1192 \\ Miriam Cabrera Corvelo Delboni² \\ https://orcid.org/0000-0001-5049-4561 \\ Elenir Fedosse ${ }^{1}$ \\ https://orcid.org/0000-0002-9691-7491
}

Universidade Federal de Santa Maria UFSM, Programa de Pós-graduação em Distúrbios da Comunicação Humana, Santa Maria, Rio Grande do Sul, Brasil. Universidade Federal de Santa Maria - UFSM, Departamento de Terapia Ocupacional, Santa Maria, Rio Grande do Sul, Brasil.

Research support source: Coordination for the Improvement of Higher Education Personnel-CAPES.

Conflict of interests: Nonexistent

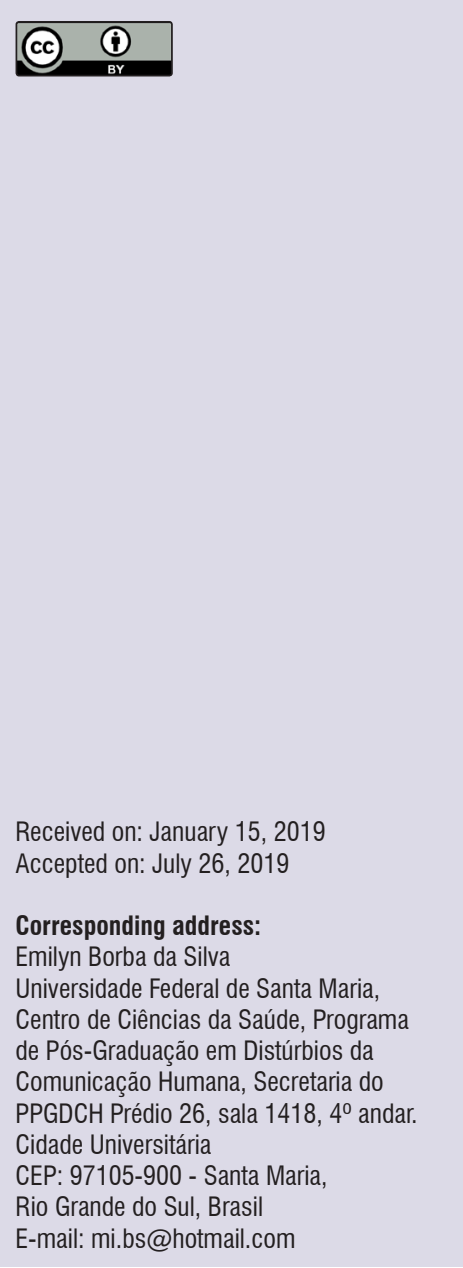

\section{ABSTRACT}

Objective: to analyze which evaluations are used by occupational therapists, speechlanguage pathologists and physiotherapists on individuals presented with aphasia and what these evaluations address.

Methods: the study conducted a national and international documental analysis of evaluations used by professionals working on the neurological rehabilitation of adults and/or elderly individuals with aphasia, published in the last ten years (January 2008/ June 2018). This analysis was performed by an integrative review of databases LILACS, SciELO and PubMed, using the descriptors: Health Assessment or Testing, or Protocols, or Psychometrics, or Questionnaires and Rehabilitation, combined with the descriptors: Aphasia, Occupational Therapy, Speech-language Pathology and Physiotherapy.

Results: 26 studies were included, most of which were scored as level VI of scientific evidence; the years of 2013 and 2016 presented publication peaks. The studies used 54 evaluation tools, among which 13 were recurrent in the studies, mostly analyzing aspects of communication/language. It is assumed that these data are related to the fact that speech-language pathologists provide care for individuals with aphasia; however, these individuals may present other needs beyond communication, such as those related to human occupation, requiring multiprofessional and integral health care. Among the protocols, the Stroke Impact Scale (SIS) was considered the most complete, since it addresses communication, linguistic, human occupation and psycho-affective aspects.

Conclusion: this study identified the use of few instruments dedicated to individuals with aphasia related to all aspects that involve life, with predominance of protocols and evaluations that only address disabilities, highlighting the importance of assessments that address subjectivity, evaluating individuals with aphasia in all dimensions of their lives.

Keywords: Aphasia; Activities of Daily Living; Health Evaluation; Integrality in Health 


\section{INTRODUCTION}

Integrality, one of the principles of the Brazilian Unified Health System (SUS) ${ }^{1}$, calls for a broader health system and better social conditions. However, it is known that several factors lead to ineffectiveness of this principle: reductionism and fragmentation of care by health professionals ${ }^{2}$. The professionals require intersubjective knowledge of individuals about the consequences caused by pathologies in daily life ${ }^{3}$, and should also consider the priorities and singularities of individuals and the need for a multidisciplinary team acting in an interdisciplinary manner for integral care.

The sequelae after stroke cause several consequences in the daily lives of individuals. Stroke is one of the most common neurological lesions in adults; they are also the most disabling, because they cause clinical manifestations as motor deficits/hemiplegias, sensory alterations/hemiparesis and language alterations/ aphasias ${ }^{4}$.

Aphasias are alterations in the linguistic processes of meaning, which impair the functions of spoken and/or written language ${ }^{5}$ to varying degrees, directly affecting the practical life causing occupational deprivations; i.e. they cause difficulties to efficiently perform routine activities, such as writing a check, answering and sending messages by phone, reading a newspaper, talking or even understanding what is spoken ${ }^{6}$.

Aphasias cause difficulties in daily life ${ }^{5}$ and thus it is assumed that they may impair human occupations that are significant to the individual, as well as occupational roles. The roles are sets of culturally influenced behaviors that guide and help to organize the performance of social functions, such as being a father, mother, student, etc. ${ }^{7,8}$. Based on the American Association of Occupational Therapy (AOTA) ${ }^{9}$, human occupations refer to daily life activities (performed on a daily basis); they have their goals, meanings and utilities, since they occur in a context. Occupations are fundamental for the identity and personal valuation, and can be classified as: Daily Life Activities (DLA), Instrumental Daily Life Activities (IDLA), Rest and Sleep, Education, Work, Play, Leisure and Social Participation?.

Considering that language plays a fundamental role in all aspects of life (social, affective, occupational, mental etc.), and the principles of humanized and integral care, there is an evident need to know the evaluation protocols used by rehabilitation therapists to guide the singular therapeutic planning. Thus, the following guiding question was designed: which are the evaluations used on individuals with aphasia by occupational therapists, speech-language pathologists and physiotherapists, and what do they address?

\section{METHODS}

The papers were searched on the following databases: Latin American and Caribbean Health Sciences Literature (LILACS), Scientific Electronic Library Online (SciELO) and Public Medicine Library (PubMed). For selection of studies, the bibliographic survey included papers published from January 2008 to June 2018.

The search used the Descriptors of Medical Subject Headings (MeSH) and Descriptors in Health Sciences (DECS) and Boolean operators AND and OR, yielding the following combinations of papers: Health Assessment or Testing, or Protocols, or Psychometrics, or Questionnaires and Rehabilitation. These descriptors were combined with the following: Aphasia, Occupational therapy, Speech-language pathology and Physiotherapy. The corresponding descriptors were used to retrieve papers published in Portuguese, Spanish and English languages.

The study included papers published in the last 10 years, national and international studies, studies involving the use of protocols/evaluations on individuals with aphasia, adults and/or elderly individuals in neurological rehabilitation with occupational therapy, speechlanguage pathology or physiotherapy. The exclusion criteria were: studies using semi-open questionnaires, adapted questionnaires and/or of unknown authorship, pharmacological and medical therapy studies, studies evaluating caregivers and/or relatives, papers and/ or abstracts without free access, literature reviews, systematic reviews, record analyses, letters, editorials and comments.

The levels of evidence were based on the scoring of the Agency for Healthcare Research and Quality $(A H R Q)^{10}$, scored into seven levels, namely: level I - meta-analysis or systematic reviews; level II randomized controlled clinical trial; level III - clinical trial without randomization; level IV - cohort and case control studies; level $\mathrm{V}$ - systematic reviews of descriptive studies; level VI - descriptive studies; level VII - expert opinion.

These systems of evidence classification provide basis for a critical evaluation of research findings and consequently in decision-making about the incorporation of evidence into clinical practice. The papers were excluded initially by year of publication; then, 
papers and/or abstracts without free access were excluded.

Thereafter, the titles and abstracts were read, and papers that did not contain the keywords were excluded. The papers were then selected for full reading, excluding duplicates (verified by the Mendeley Desktop software) and those not involving the study subject.

\section{LITERATURE REVIEW}

The survey retrieved 5,990 papers, among which 82 on the database LILACS, two on SciELO and 5,889 on PubMed (Figure 1).

\begin{tabular}{|c|c|c|c|}
\hline Descriptors & LILACS & SciELO & PubMed \\
\hline $\begin{array}{l}\text { "Health assessment" OR "Health testing" OR "Health protocols" OR } \\
\text { "Psychometrics" OR "Questionnaires" AND "Rehabilitation" AND "Occupational } \\
\text { therapy" }\end{array}$ & 10 & 2 & 4893 \\
\hline $\begin{array}{l}\text { "Health assessment" OR "Health testing" OR "Health protocols" OR } \\
\text { "Psychometrics" OR "Questionnaires" AND "Rehabilitation" AND "Speech- } \\
\text { language pathology" }\end{array}$ & 12 & 8 & 68 \\
\hline $\begin{array}{l}\text { "Health assessment" OR "Health testing" OR "Health protocols" OR } \\
\text { "Psychometrics" OR "Questionnaires" AND "Rehabilitation" AND "Physiotherapy" }\end{array}$ & 54 & 8 & 542 \\
\hline $\begin{array}{l}\text { "Health assessment” OR “Health testing” OR “Health protocols" OR } \\
\text { "Psychometrics" OR “Questionnaires” AND “Rehabilitation” AND “Aphasia” }\end{array}$ & 6 & 1 & 386 \\
\hline Total & 82 & 19 & 5889 \\
\hline
\end{tabular}

Source: Authors

Figure 1. Systematics of electronic search on the databases

Based on the eligibility criteria (Figure 2), 186 papers were selected for full reading. However, 8 papers were duplicated and 152 were not related to the study subject, addressing issues as rehabilitation of individuals without aphasia and medical techniques and protocols. Thus, 26 papers were included and evaluated in this study, retrieved from the database LILACS and 25 from PubMed; two are national and 24 international.
The number of publications was unstable over time; there were publication peaks in 2013 and 2016 (Figure 3).

Figure 4 presents the description of papers included in this study, presenting the year of publication in decreasing order; authorship; title; objectives; instruments/protocols; and level of evidence. There was predominance of studies in level $\mathrm{VI}$, which corresponds to studies without strong evidences according to the principles of Evidence-Based Practice. 


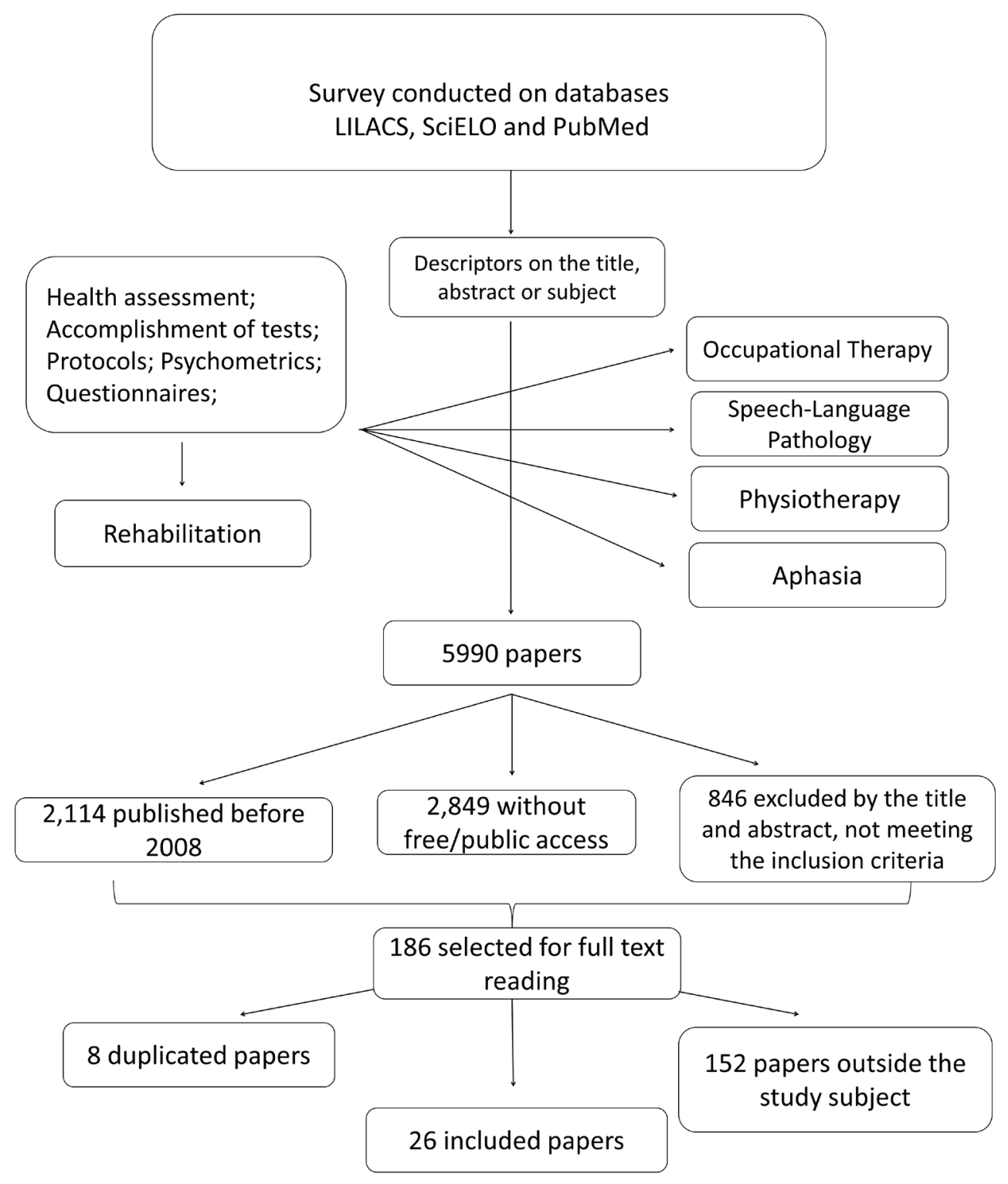

Source: Authors

Figure 2. Flowchart of literature selection process

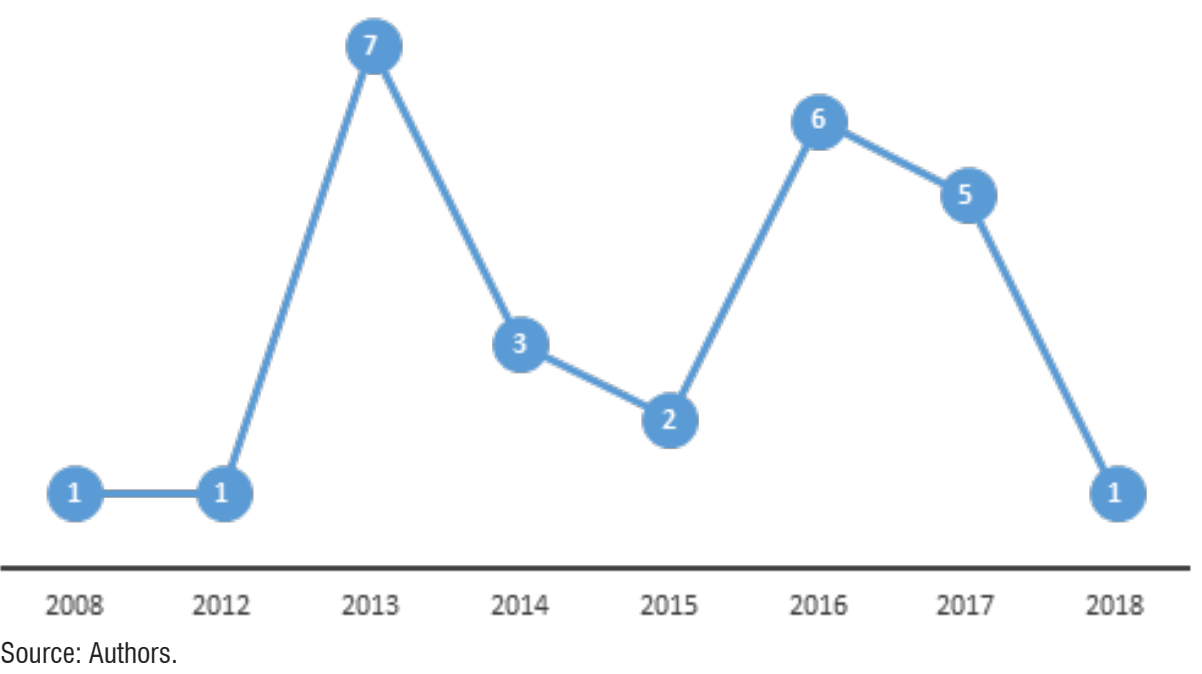

Figure 3. Number of papers included according to year of publication 


\begin{tabular}{|c|c|c|c|c|c|}
\hline Year & Author & Title & Objective & Protocol & $\begin{array}{l}\text { Level of } \\
\text { evidence }\end{array}$ \\
\hline 2018 & $\begin{array}{l}\text { KIRKEVOLD, M. } \\
\text { et al. }{ }^{11}\end{array}$ & $\begin{array}{l}\text { Promoting psychosocial well-being } \\
\text { following stroke: study protocol for a } \\
\text { randomized, controlled trial. }\end{array}$ & $\begin{array}{l}\text { To evaluate the effect of a psychosocial } \\
\text { intervention, previously developed and } \\
\text { tested for feasibility, based on dialogue, } \\
\text { aiming to promote psychosocial well- } \\
\text { being and coping after stroke among } \\
\text { stroke survivors with and without } \\
\text { aphasia. }\end{array}$ & $\begin{array}{c}\text { GHQ-28, } \\
\text { SAQ0L-39, SOC- } \\
\text { 13, Depression } \\
\text { Questionnaire } \\
\text { (Yale). }\end{array}$ & III \\
\hline 2017 & HREHA, K. et al. ${ }^{12}$ & $\begin{array}{l}\text { Assessing chronic stroke survivors } \\
\text { with aphasia sheds light on } \\
\text { prevalence of spatial neglect. }\end{array}$ & $\begin{array}{l}\text { To determine the frequency of spatial } \\
\text { neglect in chronic survivors of left-side } \\
\text { stroke with aphasia. }\end{array}$ & $\begin{array}{l}\text { BIT, CBS, The } \\
\text { Life Space } \\
\text { Questionnaire BI. }\end{array}$ & V \\
\hline 2017 & $\begin{array}{l}\text { BRANCO, J. P. } \\
\quad \text { et al. }{ }^{13}\end{array}$ & $\begin{array}{l}\text { Assessing upper limb function: } \\
\text { transcultural adaptation and } \\
\text { validation of the Portuguese version } \\
\text { of the Stroke Upper Limb Capacity } \\
\text { Scale. }\end{array}$ & $\begin{array}{l}\text { To conduct the transcultural adaptation } \\
\text { and psychometric validation of the } \\
\text { Portuguese version of SULCS. }\end{array}$ & $\begin{array}{l}\text { SULCS, EQ-5D, } \\
\text { SIS. }\end{array}$ & $\mathrm{VI}$ \\
\hline 2017 & $\begin{array}{l}\text { LOUISA, N. G. } \\
\quad \text { et al. }{ }^{14}\end{array}$ & $\begin{array}{l}\text { Effectiveness of a structured sexual } \\
\text { rehabilitation programme following } \\
\text { stroke: A randomized controlled trial. }\end{array}$ & $\begin{array}{l}\text { To evaluate the effectiveness of a } \\
\text { structured sexual rehabilitation program } \\
\text { in an Australian cohort of stroke. }\end{array}$ & $\begin{array}{l}\text { CSFQ-14, DASS- } \\
\text { 21, FIM and } \\
\text { SAQOL-39. }\end{array}$ & III \\
\hline 2017 & $\begin{array}{l}\text { FRIEDMAN, R. B } \\
\text { et al. }{ }^{15}\end{array}$ & $\begin{array}{l}\text { Leveraging the Test Effect to Improve } \\
\text { Maintenance of the Gains Achieved } \\
\text { Through Cognitive Rehabilitation }\end{array}$ & $\begin{array}{l}\text { To investigate the hypothesis that } \\
\text { continued testing of relearned words } \\
\text { in individuals with anomia leads to } \\
\text { significantly greater maintenance } \\
\text { compared to continued study of } \\
\text { relearned words. }\end{array}$ & $\begin{array}{l}\text { BNT, TONI, VFD, } \\
\text { BFLT, BDAE. }\end{array}$ & VI \\
\hline 2017 & $\begin{array}{l}\text { SKIDMORE, E. R. } \\
\text { et al. }{ }^{16}\end{array}$ & $\begin{array}{l}\text { Guided Training Relative to Direct } \\
\text { Skill Training for Individuals With } \\
\text { Cognitive Impairments After Stroke: } \\
\text { A Pilot Randomized Trial. }\end{array}$ & $\begin{array}{l}\text { To examine the effects of skill training } \\
\text { and guided training to promote } \\
\text { independence after stroke. }\end{array}$ & FIM. & $\|$ \\
\hline 2016 & $\begin{array}{l}\text { PURDY, S. C. } \\
\text { et al. }{ }^{17}\end{array}$ & $\begin{array}{l}\text { Aphasia and Auditory Processing } \\
\text { after Stroke through an International } \\
\text { Classification of Functioning, } \\
\text { Disability and Health Lens }\end{array}$ & $\begin{array}{l}\text { To analyze the effects on auditory } \\
\text { processing and their consequences on } \\
\text { activities after stroke. }\end{array}$ & ICF, BNT, CAT. & VI \\
\hline 2016 & $\begin{array}{l}\text { POMMEREHN, J; } \\
\text { DELBONI, M.C.C; } \\
\text { FEDOSSE E. }{ }^{18}\end{array}$ & $\begin{array}{l}\text { Classificação Internacional de } \\
\text { Funcionalidade, Incapacidade e } \\
\text { Saúde e aphasia: um estudo da } \\
\text { participação social. }\end{array}$ & $\begin{array}{l}\text { To identify and analyze the impact of } \\
\text { aphasia on social participation and daily } \\
\text { life activities of affected individuals. }\end{array}$ & ICF. & $\mathrm{Vl}$ \\
\hline 2016 & $\begin{array}{l}\text { KOENIG-BRUHIN, } \\
\text { M. et al. }{ }^{19}\end{array}$ & $\begin{array}{l}\text { Screening for Language Disorders } \\
\text { in Stroke: German Validation of the } \\
\text { Language Screening Test (LAST) }\end{array}$ & $\begin{array}{l}\text { To develop and validate two parallel } \\
\text { German versions of LAST. }\end{array}$ & LAST. & VI \\
\hline 2016 & $\begin{array}{l}\text { MEYER, A. M. } \\
\text { et al. }{ }^{20}\end{array}$ & $\begin{array}{l}\text { Telerehabilitation of Anomia in } \\
\text { Primary Progressive Aphasia. }\end{array}$ & $\begin{array}{l}\text { To evaluate the feasibility and efficacy } \\
\text { of a telerehabilitation-based approach } \\
\text { to anomia treatment within the three } \\
\text { subtypes of primary progressive aphasia } \\
\text { (PPA). }\end{array}$ & $\begin{array}{l}\text { MMSE, } \\
\text { MOCA, PPT, } \\
\text { Word-Picture } \\
\text { Matching, NAT, } \\
\text { BDAE, BNT. } \\
\end{array}$ & VI \\
\hline 2016 & $\begin{array}{l}\text { SACKLEY, C. M. } \\
\quad \text { et al. }{ }^{21}\end{array}$ & $\begin{array}{c}\text { An Occupational Therapy } \\
\text { intervention for residents with } \\
\text { stroke-related disabilities in UK Care } \\
\text { Homes (OTCH): cluster randomised } \\
\text { controlled trial with economic } \\
\text { evaluation. }\end{array}$ & $\begin{array}{l}\text { To evaluate the clinical effectiveness and } \\
\text { cost-effectiveness of a targeted course } \\
\text { of occupational therapy in maintaining } \\
\text { functional activity and reducing the risks } \\
\text { from inactivity for care home residents } \\
\text { living with stroke-related disabilities. }\end{array}$ & $\begin{array}{c}\text { BI, RMI, GDS, } \\
\text { EQ-D5, Sheffield } \\
\text { Screening Test } \\
\text { for Acquired } \\
\text { Language } \\
\text { Disorders, } \\
\text { MMSE. } \\
\end{array}$ & III \\
\hline 2016 & OFF, C.A. et al. ${ }^{22}$ & $\begin{array}{l}\text { The impact of dose on naming } \\
\text { accuracy with persons with aphasia }\end{array}$ & $\begin{array}{c}\text { To investigate how the manipulating dose } \\
\text { of repeated confrontation naming within } \\
\text { sessions influences naming in persons } \\
\text { with aphasia. }\end{array}$ & $\begin{array}{l}\text { BNT, WAB, } \\
\text { PALPA. }\end{array}$ & VI \\
\hline 2015 & LEE, H. et al. ${ }^{23}$ & $\begin{array}{l}\text { Community Integration and Quality of } \\
\text { Life in Aphasia after Stroke. }\end{array}$ & $\begin{array}{l}\text { To examine community integration } \\
\text { and contributing factors in people with } \\
\text { aphasia after stroke and to investigate } \\
\text { the relationship between community } \\
\text { integration and quality of life. }\end{array}$ & $\begin{array}{l}\text { BI, FAST, } \\
\text { GDS, CIQ and } \\
\text { SAQOL-39. }\end{array}$ & V \\
\hline
\end{tabular}




\begin{tabular}{|c|c|c|c|c|c|}
\hline Year & Author & Title & Objective & Protocol & $\begin{array}{l}\text { Level of } \\
\text { evidence }\end{array}$ \\
\hline 2015 & $\begin{array}{l}\text { SCRUTINIO, D. } \\
\quad \text { et al. }{ }^{24}\end{array}$ & $\begin{array}{c}\text { Functional Gain After Inpatient Stroke } \\
\text { Rehabilitation: Correlates and Impact } \\
\text { on Long-Term Survival. }\end{array}$ & $\begin{array}{l}\text { To investigate the factors associated with } \\
\text { functional outcome after rehabilitation } \\
\text { and whether the magnitude of functional } \\
\text { improvement achieved by rehabilitation is } \\
\text { associated with long-term mortality risk. }\end{array}$ & FIM. & IV \\
\hline 2014 & TAO, J. et al. ${ }^{25}$ & $\begin{array}{l}\text { Community-applied research of } \\
\text { a traditional Chinese medicine } \\
\text { rehabilitation scheme on Broca's } \\
\text { aphasia after stroke: study protocol } \\
\text { for a randomized controlled trial. }\end{array}$ & $\begin{array}{l}\text { To develop an effective standard } \\
\text { therapeutic program for apoplectic } \\
\text { aphasia in communities. }\end{array}$ & $\begin{array}{l}\text { CRRCAE, BDAE, } \\
\text { BI and SF-36. }\end{array}$ & III \\
\hline 2014 & $\begin{array}{l}\text { Skidmore, E. R. } \\
\quad \text { et al. }{ }^{26}\end{array}$ & $\begin{array}{l}\text { Developing complex interventions: } \\
\text { lessons learned from a pilot study } \\
\text { examining strategy training in acute } \\
\text { stroke rehabilitation. }\end{array}$ & $\begin{array}{l}\text { To examine the feasibility of a strategy } \\
\text { training clinical trial in a small group } \\
\text { of adults with stroke-related cognitive } \\
\text { impairments in inpatient rehabilitation, } \\
\text { and to explore the impact of strategy } \\
\text { training on disability. }\end{array}$ & FIM. & V \\
\hline 2014 & $\begin{array}{l}\text { GUIDETTI, S. } \\
\quad \text { et al. }{ }^{27}\end{array}$ & $\begin{array}{l}\text { Changes in the impact of stroke } \\
\text { between } 3 \text { and } 12 \text { months post- } \\
\text { stroke, assessed with the Stroke } \\
\text { Impact Scale. }\end{array}$ & $\begin{array}{l}\text { To examine data collected using the } \\
\text { Stroke Impact Scale (SIS) at } 3 \text { and } 12 \\
\text { months after stroke, and to explore any } \\
\text { clinically meaningful changes in daily } \\
\text { life in relation to age, gender and stroke } \\
\text { severity. }\end{array}$ & MMSE, BI, SIS. & $\mathrm{VI}$ \\
\hline 2013 & SORAIA, M. et al. ${ }^{28}$ & $\begin{array}{l}\text { Comparison of quality-of-life } \\
\text { instruments for assessing the } \\
\text { participation after stroke based on } \\
\text { the International Classification of } \\
\text { Functioning, Disability and Health } \\
\text { (ICF) }\end{array}$ & $\begin{array}{c}\text { To investigate whether the Nottingham } \\
\text { Health Profile (NHP) and Stroke Specific } \\
\text { Quality of Life (SS-QOL) are suitable for } \\
\text { assessing the participation component } \\
\text { of ICF. }\end{array}$ & NHP, SS-QOL. & V \\
\hline 2013 & $\begin{array}{l}\text { MAZAUX, J.-M. } \\
\text { et al. }{ }^{29}\end{array}$ & $\begin{array}{l}\text { Communication activity in stroke } \\
\text { patients with aphasia. }\end{array}$ & $\begin{array}{l}\text { To study the communication disability in } \\
\text { stroke patients with aphasia. }\end{array}$ & $\begin{array}{l}\text { BVCS, BDAE, OS } \\
\text { and ADRS. }\end{array}$ & V \\
\hline 2013 & $\begin{array}{l}\text { BAUMGAERTNE,R. } \\
\text { et al. } / 2013 .^{30}\end{array}$ & $\begin{array}{l}\text { FCET2EC (From controlled } \\
\text { experimental trial to = } 2 \text { everyday } \\
\text { communication): How effective } \\
\text { is intensive integrative therapy for } \\
\text { stroke-induced chronic aphasia } \\
\text { under routine clinical conditions? } \\
\text { A study protocol for a randomized } \\
\text { controlled trial. }\end{array}$ & $\begin{array}{l}\text { To examine whether intensive integrative } \\
\text { language therapy provided in routine } \\
\text { in- and outpatient clinics is effective in } \\
\text { improving the daily life communication in } \\
\text { chronic post-stroke aphasia. }\end{array}$ & $\begin{array}{l}\text { ANELT, } \\
\text { SAQOL-39, } \\
\text { CETI. }\end{array}$ & III \\
\hline 2013 & $\begin{array}{l}\text { GIALANELLA, } \\
\text { B; SANTORO, R; } \\
\text { FERLUCCI, C }{ }^{31} \text {. }\end{array}$ & $\begin{array}{l}\text { Predicting outcome after stroke: the } \\
\text { role of basic activities of daily living } \\
\text { predicting outcome after stroke. }\end{array}$ & $\begin{array}{l}\text { To investigate the admission functional } \\
\text { status and performance of basic DLAs as } \\
\text { assessed by the Functional Independence } \\
\text { Measure (FIM) scale as possible } \\
\text { predictors of motor and functional } \\
\text { outcome after stroke during inpatient } \\
\text { rehabilitation. }\end{array}$ & $\begin{array}{l}\text { CIRS, AAT, TCT, } \\
\text { FM, FIM, NIHSS. }\end{array}$ & $\mathrm{VI}$ \\
\hline 2013 & $\begin{array}{l}\text { HENRY, M. L. } \\
\quad \text { et } \mathrm{a} /{ }^{32}\end{array}$ & $\begin{array}{c}\text { Treatment for apraxia of speech in } \\
\text { nonfluent variant primary progressive } \\
\text { aphasia. }\end{array}$ & $\begin{array}{l}\text { To examine a novel approach for the } \\
\text { treatment of apraxia in nonfluent aphasia. }\end{array}$ & $\begin{array}{l}\text { MMSE, WAB, } \\
\text { BNT. }\end{array}$ & VI \\
\hline 2013 & $\begin{array}{l}\text { BEESON, P.M; } \\
\text { HIGGINSON, K; } \\
\text { RISING, K33. }\end{array}$ & $\begin{array}{l}\text { Writing Treatment for Aphasia: A } \\
\text { Texting Approach }\end{array}$ & $\begin{array}{l}\text { To determine whether writing treatment } \\
\text { and learning facilitation could be } \\
\text { performed by typing on a mobile, with } \\
\text { the ultimate goal of using text messaging } \\
\text { for communication. }\end{array}$ & WAB. & $\mathrm{VI}$ \\
\hline 2013 & $\begin{array}{l}\text { WEAVER, L. L. } \\
\text { et a/ }{ }^{34} \text {. }\end{array}$ & $\begin{array}{l}\text { Minimal Depression: How Does It } \\
\text { Relate to Upper-Extremity Impairment } \\
\text { and Function in Stroke? }\end{array}$ & $\begin{array}{l}\text { To determine the association between } \\
\text { minimal depression, upper-extremity } \\
\text { (UE) impairment and UE motor function } \\
\text { in a cohort of participants with subacute } \\
\text { stroke. }\end{array}$ & $\begin{array}{l}\text { FM, AMAT, } \\
\text { BDI-II. }\end{array}$ & $\mathrm{VI}$ \\
\hline
\end{tabular}




\begin{tabular}{|c|c|c|c|c|c|}
\hline Year & Author & Title & Objective & Protocol & $\begin{array}{c}\text { Level of } \\
\text { evidence }\end{array}$ \\
\hline 2012 & BOWEN, A. et I $^{35}$. & $\begin{array}{c}\text { Clinical effectiveness, cost- } \\
\text { effectiveness and service users } \\
\text { perceptions of early, well-resourced } \\
\text { communication therapy following a } \\
\text { stroke: a randomized controlled trial } \\
\text { (the ACT NoW Study) }\end{array}$ & $\begin{array}{c}\text { To determine the clinical effectiveness, } \\
\text { cost-effectiveness and service users' } \\
\text { views of enhanced early communication } \\
\text { therapy by speech-language pathologists } \\
\text { compared with attention control (AC). }\end{array}$ & TOM, EQ-D5. \\
\hline \multirow{2}{*}{2008} & KIRAN S36. & $\begin{array}{c}\text { Typicality of Inanimate Category } \\
\text { Exemplars in Aphasia Treatment: } \\
\text { Further Evidence for Semantic } \\
\text { Complexity. }\end{array}$ & $\begin{array}{c}\text { To investigate the typicality treatment } \\
\text { approach on improving naming within } \\
\text { 2 inanimate categories (furniture } \\
\text { and clothing) using a single-subject } \\
\text { experimental design in participants and } \\
\text { behaviors in 5 patients with aphasia. }\end{array}$ & $\begin{array}{c}\text { BNT, PALPA, } \\
\text { PPT, WAB. }\end{array}$ & III \\
\hline
\end{tabular}

Legend: AAT- Aachen Aphasia Test; AMAT - Arm Motor Ability Test; BDI-II - Beck Depression Inventory; BFLT-Biber Figure Learning Test; BDAE -Boston Diagnostic Aphasia Examination; BNT- Boston Naming Test; CRRCAE- China rehabilitation research center aphasia examination; ICF- International Classification of Functionality, Incapacity and Health; CETI- Communicative effectiveness index: CIQ -Community Integration Questionnaire; CIRS - Cumulative Illness Rating Scale; DASS-21- Depression, Anxiety Stress Scale (DASS-21); BVCS- Bordeaux Verbal Communication Scale; ADRS- Aphasic Depression Rating Scale; GDS- Geriatric Depression Scale; OS- Orgogozo score; ED-D5EuroQol five dimensions questionnaire; FAST- Frenchay aphasia Screening Test; FM- Fugl-Meyer scale; GHQ-28- General Health Questionnaire; BI- Barthel Index; LASTLanguage Screening Test; FIM- Functional Independence Measure; MMSE- Mini-Mental State Examination; MoCA- Montreal Cognitive Assessment; MESUPES- Motor evaluation scale for upper extremity in stroke; NIHSS- National Institutes of Health Stroke Scale; NHP- Nottingham Health Profile; PALPA- Psycholinguistic Assessments of Language Processing in Aphasia; RMI- Rivermead Mobility Index; ANELT- Scale of the Amsterdam-Nijmegen Everyday Language Test; SOC-13- Sense of Coherence; CSFQ-14- Sexual Functioning Questionnaire Short Form; SF-36- Short Form Health Survey; Stroke and Aphasia Quality of Life Scale-39 (SAQOL-39); SIS- Stroke Impact Scale; SS-QOL- Stroke Specific Quality of Life; TONI- Test of Nonverbal Intelligence; BIT- The Behavioral Inattention Test-conventional; PPT- The Pyramids and Palm Trees Test; SULCS- The Stroke Upper Limb Capacity Scale; TOM- Therapy Outcome Measure activity subscale; TCT- Trunk Control Test; VFD- Visual Form Discrimination Test; WAB- Western Aphasia Battery-Revised; NAT- Wh-questions from the Northwestern Anagram Test.

Source: Authors.

Figure 4. Presentation of main information analyzed on the selected papers

To enhance the systematization and clarity, Figure 5 presents the 54 protocols addressed in the papers, as well as the number of papers using such instruments.

It should be mentioned that the ICF is not an evaluation instrument; rather, it is a classification instrument for identification of aspects related to structures, functions, activity and participation. It was included in this study because of its relevance for understanding the subjective needs of individuals, and especially because the referred study addresses individuals with aphasia ${ }^{18}$. Among the evaluations, the Barthel Index (BI) was the most used, being present in six studies, followed by Stroke and Aphasia Quality of Life Scale-39 (SAQOL-39) in five studies, Functional Independence Measure (FIM) in five studies, EuroQol five dimensions questionnaire (EQ-D5), Boston Naming Test (BNT) and Mini-Mental State Examination (MMSE) in four studies, Boston Diagnostic Aphasia Examination (BDAE) and Western Aphasia Battery-Revised (WAB) in three studies, Stroke Impact Scale (SIS), Geriatric Depression
Scale (GDS), the Community Integration Questionnaire $(\mathrm{CIQ})$, the Scale of the Amsterdam-Nijmegen Everyday Language Test (ANELT) and the Fugl-Meyer Scale (FM) in two studies; the remaining evaluations cited were used in only one study.

Figure 6 shows the analysis of evaluation instruments (13), present in two or more studies, concerning the evaluation of communicative/linguistic aspects, aspects of human occupation (Daily Life Activities [DLA], Instrumental Daily Life Activities [IDLA], Rest and Sleep, Education, Work, Play, Leisure and Social Participation [AOTA, 2015]), as well as psycho-affective conditions. The following criteria were used for analysis "yes", "no", or "implicit". The criterion "yes" or "no" was used when the evaluation uses or not categories or dimensions that evaluate the referred aspects. The implicit criterion was used when the evaluation does not present the category nor the dimension related to such criteria; however, the approach of these aspects is implicit in the protocol questions. 


\begin{tabular}{|c|c|}
\hline Health protocols/evaluations & $\mathbf{n}$ \\
\hline Aachen Aphasia Test (AAT) & 1 \\
\hline Albert's test & 1 \\
\hline Arm Motor Ability Test (AMAT) & 1 \\
\hline Beck Depression Inventory (BDI-II) & 1 \\
\hline Biber Figure Learning Test (BFLT) & 1 \\
\hline Bisiach's test & 1 \\
\hline Boston Diagnostic Aphasia Examination (BDAE) & 3 \\
\hline Boston Naming Test (BNT) & 4 \\
\hline Catherine Bergego Scale via Kessler Foundation Neglect Assessment Process (CBS via KF-NAP) & 1 \\
\hline China rehabilitation research center aphasia examination (CRRCAE) & 1 \\
\hline Classificação Internacional de Funcionalidade, Incapacidade e Saúde (CIF) & 1 \\
\hline Communicative effectiveness index (CETI): & 1 \\
\hline Community Integration Questionnaire (CIQ) & 2 \\
\hline Cumulative Illness Rating Scale (CIRS) & 1 \\
\hline Depression, Anxiety Stress Scale (DASS-21) & 1 \\
\hline Echelle de Comunicação Verbal de Bordéus (ECVB) & 1 \\
\hline Escala de Depressão de Afasia (ADRS) & 1 \\
\hline Escala Geriátrica de Depressão (GDS) & 2 \\
\hline Escore de Orgogozo (OS) & 1 \\
\hline EuroQol five dimensions questionnaire (EQ-D5) & 4 \\
\hline Frenchay fasia Screening Test (FAST) & 1 \\
\hline Fugl-Meyer Escala (FM) & 2 \\
\hline General Health Questionnaire (GHQ-28) & 1 \\
\hline Indice de Barthel (IB): & 6 \\
\hline Language Screening Test (LAST) & 1 \\
\hline Medida de Independência Funcional (MIF): & 5 \\
\hline Mini-Mental State Examination (MMSE) & 4 \\
\hline Montreal Cognitive Assessment (MoCA) & 1 \\
\hline Motor evaluation scale for upper extremity in stroke (MESUPES) & 1 \\
\hline National Institutes of Health Stroke Scale (NIHSS) & 1 \\
\hline Nottingham Health Profile (NHP) & 1 \\
\hline Psycholinguistic Assessments of Language Processing in Aphasia (PALPA) & 1 \\
\hline Questionário de Depressão (Yale) & 1 \\
\hline Rivermead Mobility Index (RMI) & 1 \\
\hline Scale of the Amsterdam-Nijmegen Everyday Language Test (ANELT): & 2 \\
\hline Sense of Coherence (SOC-13) & 1 \\
\hline Sexual Functioning Questionnaire Short Form (CSFQ-14) & 1 \\
\hline Short Form Health Survey (SF-36) & 1 \\
\hline Stroke and Aphasia Quality of Life Scale-39 (SAQ0L-39) & 5 \\
\hline Stroke Impact Scale (SIS): & 2 \\
\hline Stroke Specific Quality of Life (SS-QOL) & 1 \\
\hline Test of Nonverbal Intelligence (TONI) & 1 \\
\hline The Behavioral Inattention Test-conventional (BIT) & 1 \\
\hline The Life Space Questionnaire & 1 \\
\hline The Pyramids and Palm Trees Test (PPT) & 1 \\
\hline The Sheffield Screening Test for Acquired Language Disorders & 1 \\
\hline The Stroke Upper Limb Capacity Scale (SULCS) & 1 \\
\hline Therapy Outcome Measure activity subscale (TOM) & 1 \\
\hline Trunk Control Test (TCT) & 1 \\
\hline Visual Form Discrimination Test (VFD) & 1 \\
\hline Western Aphasia Battery-Revised (WAB) & 3 \\
\hline Wh-questions from the Northwestern Anagram Test (NAT) & 1 \\
\hline Word-Picture Matching & 1 \\
\hline
\end{tabular}

Legend: $n$ - number of papers

Source: Authors

Figure 5. Evaluation instruments used in papers included in this study 


\begin{tabular}{lccc}
\hline Health protocols/Evaluations & $\begin{array}{c}\text { Communicative/ } \\
\text { linguistic }\end{array}$ & Human occupation & $\begin{array}{c}\text { Psycho-affective } \\
\text { conditions }\end{array}$ \\
\hline Boston Diagnostic Aphasia Examination (BDAE) & Yes & No & No \\
Boston Naming Test (BNT) & Yes & No & No \\
Community Integration Questionnaire (CIQ) & Implicit & Yes & Implicit \\
Geriatric depression scale (GDS) & No & No & Yes \\
EuroQol five dimensions questionnaire (EQ-D5) & No & Yes & Yes \\
Fugl-Meyer Scale (FM) & No & Implicit & No \\
Barthel Index (BI): & No & Yes & No \\
Functional Independence Measure (FIM): & Yes & Yes & Implicit \\
Mini-Mental State Examination (MMSE) & Yes & Implicit & No \\
Scale of the Amsterdam-Nijmegen Everyday Language & Yes & No & No \\
Test (ANELT): & Yes & Implicit & Yes \\
Stroke and Aphasia Quality of Life Scale-39 (SAQOL-39) & Yes & Yes & Yes \\
Stroke Impact Scale (SIS): & Yes & No & No \\
Western Aphasia Battery-Revised (WAB) & & & \\
\hline
\end{tabular}

Source: Authors

Figure 6. Analysis of approach of evaluations

It should be mentioned that there are few studies addressing individuals with aphasia, especially due to the difficulty to apply the evaluations to deal with linguistic-cognitive alterations ${ }^{37}$. This condition may also explain the fact that publications were unstable over the years.

Most papers used multiple evaluations, with predominance of approach of communicative/linguistic aspects. It is inferred that this predominance occurs because researches related to aphasia are mostly performed by speech-language pathologists. Thus, it is understood that occupational therapists and physiotherapists address physical aspects in their research, such as functionality, independence and activities related to human occupation. Thus, communication is implicitly evaluated in social dimensions or aspects. It is suggested that this result reflects the fragmented view of healthcare professionals.

Among the evaluations included in this study, the SIS scale is the most complete, since it addresses communication/linguistic, human occupation and psychoaffective aspects. SIS is a multidimensional instrument that evaluates the aspects involved in stroke. It consists of 64 items that evaluate 8 domains: strength, hand function, daily life activities (DLA)/instrumental daily life activities (IDLA), mobility, communication, emotion, memory and thinking and participation. Another study ${ }^{38}$, which comprised an integrative review on the quality of life of individuals with aphasia, stated that SIS was the specific instrument of quality of life assessment most used among the studies.

Evaluations performed on individuals with aphasia should address aspects beyond language, requiring evaluation of the individual as a whole, i.e. by all health professionals ${ }^{39}$. The authors of this study, supported by the Franchian conception, emphasize that language is constructed as a meaningful (formal system/language) and communicative system, organizing all cognitive processes and constituting the individual that uses it, its interactions with the physical and social world. Thus, the adoption of biopsychosocial models that address all aspects of human health, evaluations/protocols that enable multidimensional understanding of the impact of aphasia on life is fundamental.

Health actions should allow conceptions of the individual in his or her entirety, approaching the real context, without dissociating the history, singularities, daily life, process of health practices, aiming at a reflexive, integral and humanized health action ${ }^{40}$. For the true application of integrality, health professionals should stop the reductionism and fragmentation of care.

Finally, this study highlights the importance of evaluations that deal with subjectivity, analyzing the individual with aphasia in all dimensions of life. This evidences the importance of putting the individuals in first place in all therapeutic processes, allowing the selfknowledge of their lives and their real health conditions and needs. 
As a limitation, this study presents absence of some important evaluation instruments used in studies that are not publicly available. Also, it is noteworthy that, even offering a broad overview of the evaluation instruments/protocols used on individuals with aphasia, an integrative review may not represent the set of studies in a given area due to the indexing databases and descriptors used, and may not include studies found by other search methods.

\section{CONCLUSION}

This study observed a broad scenery, 54 protocols, used to evaluate the individual with aphasia by rehabilitation therapists in papers published in the last 10 years. A total of 13 protocols (used in two or more studies) were included in the analysis, among which the SIS was considered the most complete one, since it addresses communication/linguistic, human occupation and psycho-affective aspects.

The results of the literature review demonstrate the utilization of few instruments addressing individuals with aphasia related to all aspects of life, with predominance of protocols and evaluations directed only to disabilities, not addressing the individuality and not directing to a caring that recognizes the real concerns, insecurities and needs.

\section{REFERENCES}

1. Brasil. Lei n. 8.080, de 19 de setembro de 1990; Brasília: 1990. [Acesso em 30 de ago 2018]; Disponível em: http://prattein.com.br/home/ images/stories/Saude/Lei-org-saude.pdf.

2. Bergamaschi FPR, Teles AS, Souza ACS, Nakatami AYK. Reflexões acerca da integralidade nas reformas sanitária e agrária. Texto contexto - enferm. 2012;21(3):667-74. doi: 10.1590/ S0104-07072012000300023.

3. Mattos RA. A integralidade na prática (ou sobre a prática da integralidade). Cad Saúde Pública. 2004;20(5):1411-6. doi: 10.1590/ S0102-311X2004000500037.

4. Cambier J, Masson M, Dehen H. Neurologia. 11. ed. Rio de Janeiro: Guanabara Koogan; 2005.

5. Coudry MIH. A linguagem em funcionamento na afasia. Letras de Hoje. 2001;36(3):449-55.

6. Morato EM, Tubero AL, Santana AP, Damasceno B, De Souza FF, Macedo $\mathrm{HO}$ et al. Sobre as afasias e os afásicos: Subsídios teóricos e práticos elaborados pelo Centro de Convivência de Afásicos
(Universidade Estadual de Campinas). São Paulo: Unicamp; 2002.

7. American Occupational Therapy Association. Occupational therapy practice framework: domain and process (2nd). Am J Occup Ther. 2008;62(6):625-83.

8. Paiva JS. Avaliação dos papéis ocupacionais e qualidade de vida do paciente pé diabético [Monografia de Conclusão de Curso]. Brasília (DF): Universidade de Brasília - UNB, Curso de Terapia Ocupacional; 2015.

9. American Occupational Therapy Association. Estrutura da prática da Terapia Ocupacional: domínio \& processo-traduzida. Rev Ter Ocup Univ São Paulo. 2015;26(esp):1-49. doi:10.11606/ issn.2238-6149.v26iespp1-49.

10. Melnyk BM, Fineout-Overholt E. Making the case for evidence-based practice. In: (orgs). Evidence based practice in nursing \& healthcare. A guide to best practice. Philadelphia: Lippincot Williams \& Wilkin; 2005. p.3-24.

11. Kirkevold M, Bragstad LK, Bronken BA, Kvigne K, Martinsen R, Hjelle EG et al. Promoting psychosocial well-being following stroke: study protocol for a randomized, controlled trial. BMC Psychology. 2018;6(1):12. doi:10.1186/s40359-018-0223-6.

12. Hreha K, Mulry C, Gross $M$, Jedziniak $T$, Gramas $\mathrm{N}$, Ohevshalom $\mathrm{L}$ et al. Assessing chronic stroke survivors with aphasia sheds light on prevalence of spatial neglect. Topics in Stroke Rehabilitation. 2017;24(2):91-8. doi:10.1080/10749357.2016.119 6906

13. Branco JP, Oliveira S, Pinheiro JP, Ferreira PL. Assessing upper limb function: transcultural adaptation and validation of the Portuguese version of the Stroke Upper Limb Capacity Scale. BMC Sports Sci Med Rehabil. 2017;9:15. Published 2017 Aug 3. doi:10.1186/s13102-017-0078-9.

14. Ng L, Sansom J, Zhang N, Amatya B, Khan F. Effectiveness of a structured sexual rehabilitation programme following stroke: a randomized controlled trial. J Rehabil Med. 2017;49(4):333-40. doi:10.2340/16501977-2219.

15. Friedman RB, Sullivan KL, Snider SF, Luta G, Jones KT. Leveraging the test effect to improve maintenance of the gains achieved through cognitive rehabilitation. Neuropsychology. 2017;31(2):220-8. doi:10.1037/neu0000318.

16. Skidmore ER, Butters M, Whyte E, Grattan E, Shen $\mathrm{J}$, Terhorst $\mathrm{L}$. Guided training relative to direct skill 
training for individuals with cognitive impairments after stroke: a pilot randomized trial. Arch Phys Med Rehabil. 2017;98(4):673-80. doi:10.1016/j. apmr.2016.10.004.

17. Purdy SC, Wanigasekara I, Cañete OM, Moore C, McCann CM. Aphasia and auditory processing after stroke through an International Classification of Functioning, Disability and Health Lens. Seminars in Hearing. 2016;37(3):233-46. doi:10.1055/s-0036-1584408.

18. Pommerehn J, Delboni MCC, Fedosse E. International Classification of Functioning, Disability and Health, and aphasia: a study of social participation. CoDAS. 2016;28(2):132-40. doi:10.1590/2317-1782/201620150102.

19. Koenig-Bruhin $M$, Vanbellingen $T$, Schumacher R, Pflugshaupt T, Annoni JM, Müri RM et al. Screening for language disorders in stroke: german validation of the Language Screening Test (LAST). Cerebrovasc Dis Extra. 2016;6(1):27-31. doi:10.1159/00044577819.

20. Meyer AM, Getz HR, Brennan DM, Hu TM, Friedman RB. Telerehabilitation of anomia in primary progressive aphasia. Aphasiology. 2016;30(4):483507. doi:10.1080/02687038.2015.1081142.

21. Sackley CM, Walker MF, Burton CR, Watkins CL, Mant J, Roalfe AK et al. An Occupational Therapy intervention for residents with strokerelated disabilities in UK Care Homes (OTCH): cluster randomised controlled trial with economic evaluation. Health Technol Assess. 2016;20(15):1138. doi: 10.3310/hta20150.

22. Off CA, Griffin JR, Spencer KA, Rogers M. The impact of dose on naming accuracy with persons with aphasia. Aphasiology. 2016;30(9):983-1011. doi:10.1080/02687038.2015.1100705.22.

23. Lee $H$, Lee $Y$, Choi H, Pyun S-B. Community integration and quality of life in aphasia after stroke. Yonsei Med J. 2015;56(6):1694-702. doi:10.3349/ ymj.2015.56.6.1694.

24. Scrutinio D, Monitillo V, Guida P, Nardulli R, Multari $\mathrm{V}$, Monitillo $\mathrm{F}$ et al. Functional gain after inpatient stroke rehabilitation. Stroke. 2015;46(10):2976-80. doi: 10.1161/STROKEAHA.115.010440.

25. Tao J, Fang $Y$, Wu Z, Rao T, Su Y, Lin L et al. Community-applied research of a traditional Chinese medicine rehabilitation scheme on Broca's aphasia after stroke: study protocol for a randomized controlled trial. Trials. 2014;15:290. Published 2014 Jul 21. doi:10.1186/1745-6215-15-290.
26. Skidmore ER, Dawson DR, Whyte EM, Butters MA, Dew MA, Grattan ES et al. Developing complex interventions: lessons learned from a pilot study examining strategy training in acute stroke rehabilitation. Clin Rehabil. 2014;28(4):378-87. doi: 10.1177/0269215513502799.

27. Guidetti S, Ytterberg C, Ekstam L, Johansson $\mathrm{U}$, Eriksson $\mathrm{G}$. Changes in the impact of stroke between 3 and 12 months post-stroke, assessed with the Stroke Impact Scale. J Rehabil Med. 2014;46(10):963-8. doi: 10.2340/16501977-1865.

28. Silva SM, Correa FI, Faria CDCM, Correa JCF. Comparison of quality-of-life instruments for assessing the participation after stroke based on the International Classification of Functioning, Disability and Health (ICF). Braz. J. Phys. Ther. 2013;17(5):470-8. doi: 10.1590/ S1413-35552012005000118.

29. Mazaux JM, Lagadec T, Panchoa MS, Zongo D, Asselineau J, Douce $\mathrm{J}$ et al. Communication activity in stroke patients with aphasia. J Rehabil Med. 2013;45(4):341-6. doi: 10.2340/16501977-1122.

30. Baumgaertner A, Grewe T, Ziegler W, Floel A, Springer $\mathrm{L}$, Martus $\mathrm{P}$ et al. FCET2EC (From controlled experimental trial to $=2$ everyday communication): how effective is intensive integrative therapy for stroke-induced chronic aphasia under routine clinical conditions? A study protocol for a randomized controlled trial. Trials. 2013;14:308. doi: 10.1186/1745-6215-14-308.

31. Gialanella B, Santoro R, Ferlucci C. Predicting outcome after stroke: the role of basic activities of daily living. Eur $\mathrm{J}$ of Phys and Rehabil Med. 2013;49(5):629-37.

32. Henry ML, Meese MV, Truong S, Babiak MC, Miller BL, Gorno-Tempini ML. Treatment for apraxia of speech in nonfluent variant primary progressive aphasia. Behav Neurol. 2013;26(1-2):77-88. doi:10.3233/BEN-2012-120260.

33. Beeson PM, Higginson K, Rising K. Writing treatment for aphasia: a texting approach. JSLHR. 2013;56(3):945-55. doi:10.1044/1092-4388(2012/11-0360).

34. Weaver LL, Page SJ, Sheffler L, Chae J. Minimal depression: how does it relate to upperextremity impairment and function in stroke? Am J Occup Ther. 2013;67(5):550-5. doi:10.5014/ ajot.2013.008391.

35. Bowen A, Hesketh A, Patchick E, Young A, Davies L. Clinical effectiveness, cost-effectiveness and 
service users' perceptions of early, well-resourced communication therapy following a stroke: a randomised controlled trial (the ACT NoW Study). Health Technol Assess. 2012;16(26):1-160. doi: 10.3310/hta16260.

36. Kiran S. Typicality of inanimate category exemplars in aphasia treatment: further evidence for semantic complexity. JSLHR. 2008;51(6):1550-68. doi:10.1044/1092-4388(2008/07-0038).

37. Bahia MM, Chun RYS. Quality of life in aphasia: differences between fluent and non-fluent aphasic augmentative and alternative communication users. Audiol. Commun. Res. 2014;19(4):352-9. doi: 10.1590/S2317-64312014000300001353.

38. Canuto MA, Nogueira LT. Acidente vascular cerebral e qualidade de vida: uma revisão integrativa. J. res. fundam. care. 2015;7(2):2561-8. doi: 10.9789/2175-5361.2015.v7i2.2561-2568.

39. Cernescu RP, Leite CAG, Lessa WM. Reabilitação fonoaudiológica em grupo de pacientes afásicos. UNOPAR Cient., Ciênc. Biol. Saúde. 2000;2(1):77-91. doi: 10.17921/2447-8938.2000v2n1p\%25p.

40. Silveira L, Ribeiro V. Grupo de adesão ao tratamento: espaço de "ensinagem" para profissionais de saúde e pacientes. Interface Comunic., Saúde, Educ. 2005;9(16):91-104. doi: 10.1590/S1414-32832005000100008. 